

\title{
MITE (ACARINA) POPULATIONS IN RING-BILLED GULL NESTS
}

R. FReITAG, J. P. RYder, and P. WANSON

Department of Biology, Lakehead University, Thunder Bay, Ontario

\begin{abstract}
Can. Ent. 106: 319-327 (1974)

Mites collected from 69 Larus delawarensis Ord nests on Granite Island, Lake Superior, northwestern Ontario, during the summers of 1972 and 1973 showed phenological relationships with the breeding cycle of the gulls. The populations of five selected mite genera varied in relation to nest initiation, egg laying, and egg hatching periods of the gulls. Moisture within the nests significantly affected mite population densities, whereas nest density did not.
\end{abstract}

\section{Introduction}

Considerable attention has been given to the nest arthropod fauna of various species of birds by Nolan (1955), Owen (1954), Mason (1944), Coombs (1960), Rao and Rajagopalan (1970), and Hicks (1959). Ecological relationships between birds and their associated acarine fauna studied by Woodroffe and Southgate (1951) and Woodroffe (1953) indicate that in some passerine nests, mites follow a succession from predominantly ectoparasitic forms during nest construction, incubation, and egg hatching, to mainly scavenger forms during the nestling period when debris in the nest is plentiful, to largely humus feeders, which eat decomposing material in the vacated nests. Moss (1972) suggested that the ectoparasitic mite Dermanyssus prognephilus Ewing may be a factor in regulating clutch size in purple martins, Progne subis (L.), while Phillis (1972) found that populations of two species of Dermanyssus in nests of the house sparrow, Passer domesticus (L.), correlate with the bird's nesting cycle and that maximum numbers occur during the late brood phase.

Studies on invertebrate associates of gulls have been restricted mainly to endoparasitic forms such as that described by Vermeer (1969) and Threlfall (1968)." Boyd (1949) described the sarcoptiform mite Turbinoptes stantmanni, found in the nasal cavity of the ring-billed gull, Larus delawarensis Ord. However, work on the acarine nest fauna species is lacking.

This paper identifies and enumerates mites found in nests of ring-billed gulls on Granite Island, Lake Superior, during the summers of 1972 and 1973, and determines abundance, habit, and seasonal population changes of the mite genera, two predators and three saprovores, in relation to the gull breeding cycle. A preliminary hypothesis that the nests serve as focal points of mite growth and development is considered.

\section{Materials and Methods}

Granite Island $\left(48^{\circ} 43^{\prime}\right.$ N., $88^{\circ} 29^{\prime}$ W.) is a rock outcrop $402 \mathrm{~m}$ by $201 \mathrm{~m}$ located in Black Bay, Lake Superior, $4.8 \mathrm{~km}$ from the closest mainland point on Sibley Peninsula. Bird nests are present in depressions in the rocky surface, where soil and vegetation accumulate (Ryder and Freitag 1973, unpub.).

Sixty-nine nests were collected from the ring-billed gull colony on the island from May through July 1972 and 1973. Samples of leaf litter were collected from the mainland and Granite Island as controls.

The nests were wet-weighed on a Mettler electric balance, then placed in Berlese funnels, following the method described by Nolan (1955). The extraction of invertebrates required an average of 5 days, depending on the wetness of the nests. After removal of the invertebrates, the nests were dried and reweighed. 
Mites were counted and separated from other invertebrates, using a Wild M-5 stereoscopic microscope, and stored in 8-dr vials containing $70 \%$ ethanol. For reference and identification mites and other small arthropods were transferred to Hoyer's mounting medium on slides, and cleared and dried in an oven at $40^{\circ} \mathrm{C}$ for 1 week, after which they were photographed and identified.

Figures of seasonal changes in the total mite population were compared with corresponding figures of the gull breeding cycle for the same term. Similar figures on population changes in five selected mite genera were prepared from the 1973 data. For purposes of constructing tables and figures absolute numbers of mites were converted to relative density measurements (mites per $100 \mathrm{~g}$ of dry nest weight). This eliminated the variables of nest size and water content.

\section{Mite Phenologies}

\section{Results}

Table I shows numbers of collected mites per nest and dry nest weights, and average weekly densities of the mites and their conversion to percentages of the total for 1972. A total of 6,170 mites was recovered. The total mean mite density per $100 \mathrm{~g}$ dry nest weight for 1972 was $44.7 \pm 56.9$. Two small peaks and one large peak were found during the weeks of 26 May -1 June, 15-21 June, and 29 June -6 July with weekly mite densities per $100 \mathrm{~g}$ dry nest weight of $45.8 \pm 75$, $70.7 \pm 51.8$, and $181.8 \pm 38.4$ respectively.

Table I. Phenology of total mite population in ring-billed gull nests (1972)

\begin{tabular}{|c|c|c|c|c|c|}
\hline Date & Nest No. & No. mites & $\begin{array}{c}\text { Dry nest } \\
\text { wt. }(\mathrm{g})\end{array}$ & $\begin{array}{l}\text { No. mites } / 100 \mathrm{~g} / \\
\text { nest wt. } / \text { wk } \\
\text { (士S.D.) }\end{array}$ & $\begin{array}{l}\text { Per cent } \\
\text { of total }\end{array}$ \\
\hline May 19 & $\begin{array}{l}1 \\
2 \\
3 \\
4 \\
5\end{array}$ & $\begin{array}{r}0 \\
2 \\
2 \\
13 \\
0\end{array}$ & $\begin{array}{l}210 \\
115 \\
110 \\
225 \\
105\end{array}$ & $2.8 \pm 2.4$ & 0.7 \\
\hline May 26 & $\begin{array}{r}6 \\
7 \\
8 \\
9 \\
10\end{array}$ & $\begin{array}{r}13 \\
224 \\
7 \\
14 \\
77\end{array}$ & $\begin{array}{r}55 \\
125 \\
295 \\
165 \\
510\end{array}$ & $45.8 \pm 75.0$ & 10.6 \\
\hline June 2 & $\begin{array}{l}11 \\
12 \\
13\end{array}$ & $\begin{array}{r}438 \\
329 \\
50\end{array}$ & $\begin{array}{r}1470 \\
460 \\
450\end{array}$ & $37.5 \pm 30.9$ & 8.7 \\
\hline June 9 & $\begin{array}{l}14 \\
15 \\
16\end{array}$ & $\begin{array}{r}109 \\
30 \\
33\end{array}$ & $\begin{array}{l}495 \\
575 \\
230\end{array}$ & $13.9 \pm 8.4$ & 3.2 \\
\hline June 15 & $\begin{array}{l}17 \\
18 \\
19\end{array}$ & $\begin{array}{l}558 \\
651 \\
138\end{array}$ & $\begin{array}{r}600 \\
605 \\
1205\end{array}$ & $70.7 \pm 51.8$ & 16.5 \\
\hline June 22 & $\begin{array}{l}20 \\
21 \\
22\end{array}$ & $\begin{array}{l}568 \\
480 \\
261\end{array}$ & $\begin{array}{r}1620 \\
1110 \\
815\end{array}$ & $36.8 \pm 5.8$ & 8.5 \\
\hline June 29 & $\begin{array}{l}23 \\
24\end{array}$ & $\begin{array}{l}657 \\
491\end{array}$ & $\begin{array}{l}425 \\
235\end{array}$ & $181.8 \pm 38.4$ & 42.2 \\
\hline July 7 & $\begin{array}{l}25 \\
26 \\
27\end{array}$ & $\begin{array}{l}641 \\
119 \\
265\end{array}$ & $\begin{array}{l}995 \\
704 \\
620\end{array}$ & $41.4 \pm 23.8$ & 9.6 \\
\hline
\end{tabular}


Table II. Phenology of total mite population in ring-billed gull nests (1973)

\begin{tabular}{|c|c|c|c|c|c|c|}
\hline Date & Nest No. & $\begin{array}{l}\text { Moisture } \\
\text { condition* }\end{array}$ & No. mites & $\begin{array}{l}\text { Dry nest } \\
\text { wt. }(g)\end{array}$ & $\begin{array}{l}\text { No. mites } / 100 \mathrm{~g} / \\
\text { nest wt. } / \text { wk } \\
\text { (士S.D.) }\end{array}$ & $\begin{array}{l}\text { Per cent } \\
\text { of total }\end{array}$ \\
\hline May 9 & $\begin{array}{l}1 \\
2 \\
3 \\
4 \\
5\end{array}$ & $\begin{array}{l}\bar{z} \\
\bar{z}\end{array}$ & $\begin{array}{r}71 \\
165 \\
199 \\
138 \\
77\end{array}$ & $\begin{array}{r}175 \\
295 \\
305 \\
140 \\
85\end{array}$ & $70.2 \pm 24.1$ & 6.7 \\
\hline May 17 & $\begin{array}{r}6 \\
7 \\
8 \\
9 \\
10\end{array}$ & $\begin{array}{l}D \\
D \\
D \\
W \\
D\end{array}$ & $\begin{array}{r}171 \\
461 \\
118 \\
55 \\
27\end{array}$ & $\begin{array}{r}105 \\
300 \\
275 \\
95 \\
130\end{array}$ & $87.6 \pm 65.9$ & 8.4 \\
\hline May 25 & $\begin{array}{l}11 \\
12 \\
13 \\
14 \\
15\end{array}$ & $\begin{array}{l}W \\
D \\
D \\
D \\
W\end{array}$ & $\begin{array}{r}189 \\
267 \\
92 \\
243 \\
343\end{array}$ & $\begin{array}{l}335 \\
430 \\
255 \\
320 \\
310\end{array}$ & $46.3 \pm 29.1$ & 4.4 \\
\hline June 1 & $\begin{array}{l}16 \\
17 \\
18 \\
19 \\
20\end{array}$ & $\begin{array}{l}D \\
D \\
D \\
W \\
W\end{array}$ & $\begin{array}{r}568 \\
27 \\
373 \\
1523 \\
2090\end{array}$ & $\begin{array}{l}660 \\
290 \\
395 \\
495 \\
520\end{array}$ & $119.0 \pm 163.8$ & 11.4 \\
\hline June 10 & $\begin{array}{l}21 \\
22 \\
23 \\
24 \\
25\end{array}$ & $\begin{array}{l}W \\
D \\
D \\
W \\
W\end{array}$ & $\begin{array}{r}791 \\
1011 \\
767 \\
170 \\
1226\end{array}$ & $\begin{array}{l}700 \\
790 \\
440 \\
160 \\
485\end{array}$ & $154.9 \pm 60.8$ & 14.8 \\
\hline June 15 & $\begin{array}{l}26 \\
27 \\
28 \\
29 \\
30\end{array}$ & $\begin{array}{l}W \\
W \\
D \\
W \\
D\end{array}$ & $\begin{array}{r}1587 \\
188 \\
760 \\
124 \\
750\end{array}$ & $\begin{array}{l}420 \\
210 \\
540 \\
140 \\
670\end{array}$ & $161.7 \pm 122.7$ & 15.5 \\
\hline June 21 & $\begin{array}{l}31 \\
32 \\
33 \\
34 \\
35\end{array}$ & $\begin{array}{l}\text { W } \\
D \\
D \\
D \\
W\end{array}$ & $\begin{array}{r}1455 \\
550 \\
481 \\
211 \\
702\end{array}$ & $\begin{array}{l}340 \\
455 \\
450 \\
285 \\
275\end{array}$ & $198.2 \pm 148.8$ & 19.1 \\
\hline June 29 & $\begin{array}{l}36 \\
37 \\
38 \\
39 \\
40\end{array}$ & $\begin{array}{l}D \\
W \\
D \\
W \\
D\end{array}$ & $\begin{array}{l}182 \\
261 \\
387 \\
396 \\
693\end{array}$ & $\begin{array}{l}345 \\
105 \\
505 \\
345 \\
195\end{array}$ & $169.6 \pm 128.5$ & 16.3 \\
\hline July 15 & $\begin{array}{l}41 \\
42\end{array}$ & - & $\begin{array}{r}39 \\
180\end{array}$ & $\begin{array}{l}200 \\
345\end{array}$ & $35.8 \pm 23.1$ & 3.4 \\
\hline
\end{tabular}

${ }^{*} D$, nest from dry habitat (bare rock); $W$, nest from moist area (grassy clump).

Table II shows similar data for 1973, as well as the moisture conditions of the habitat where the nests were found (either wet or dry). A total of 19,909 mites was counted. The total mite density of mites per $100 \mathrm{~g}$ dry nest weight for 1973 was $121.8 \pm 107.8$. Maxima in population density occurred during the weeks of 17-24 May and 21-28 June with $87.6 \pm 65.9$ and $198.2 \pm 148.8$ mites per $100 \mathrm{~g}$ dry nest weight respectively. Also, a plateau in mite density was reached beginning 1 June. 
Mite densities in leaf litter samples were lower than in nests from the corresponding time period. Mainland leaf litter, collected 29 June, had a mite density of 3.3 mites per $100 \mathrm{~g}$ dry weight of litter, whereas the mean mite density for nests at this time was $169.6 \pm 128.5$. Island leaf litter, collected $15 \mathrm{July}$, had a mite density of 15.4 as compared with $35.8 \pm 23.1$ for nests.

Total densities in 1973 (mites per gram dry weight of nest) in nests from wet and dry habitats were $1.8 \pm 1.4$ and $1.0 \pm 0.8$ respectively. This difference is significant at the $5 \%$ level.

Comparisons of figures on nest densities of mites for 1973 based on the density of surrounding gull nests, expressed as the total number of nests within a $10 \mathrm{ft}$ diameter circle of the one being considered, resulted in no significant differences.

The total number of mites recovered for each of the selected mite genera was as follows: Ameroseius spp. 44; Belbodamaeus spp. 110; Galumna spp. 1,288; Ololaelaps spp. 62; and Parasitus spp. 6,873. Table III shows mean weekly densities for the five genera, and the corresponding percentages. Total mean densities

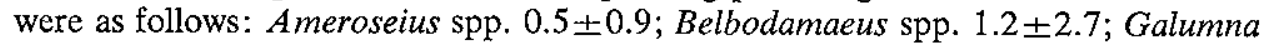
spp. $8.2 \pm 19.2$; Ololaelaps spp. $0.4 \pm 1.6$; and Parasitus spp. $35.5 \pm 66.5$.

The five genera showed marked differences in their phenologies. The Ameroseius species had a small peak at the beginning of the gull nesting season (9-16 May). Its mean density then was $0.7 \pm 0.5$. The major peak density for this genus $(1.0 \pm 2.1)$ occurred in the period of 29 June -4 July.

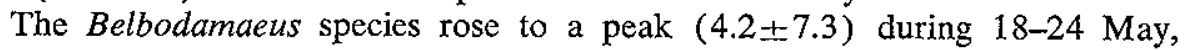
while a smaller peak $(1.2 \pm 1.3)$ occurred in the week of 21-27 May.

The Galumna species showed a small initial peak density $(6 \pm 9.6)$ in the week of 9-16 May. Population density was at a maximum $(24.6 \pm 53.2)$ in the period $1-8$ June, and a moderate increase $(13.9 \pm 14.8)$ occurred in the period 15-20 June.

Ololaelaps species showed two peaks, the first $(2.3 \pm 4.5)$ in the period $25-31$ May, followed by a small rise $(0.4 \pm 0.5)$ in the week of $21-28$ June.

The species of Parasitus rose to two maxima, the first $(10.4 \pm 18.5)$ in the week 18-24 May being a very minor one. The major peak density $(103.4 \pm 92.0)$ occurred in the period 10-14 June.

Table III. Phenology of five mite genera in ring-bilied gull nests (1973)

\begin{tabular}{|c|c|c|c|c|c|}
\hline \multirow[b]{2}{*}{ Date } & \multicolumn{5}{|c|}{ Average no. of mites $/ 100 \mathrm{~g} /$ dry nest wt. \pm S.D. } \\
\hline & $\mathrm{A}^{*}$ & $\mathrm{~B}$ & G & $\mathrm{O}$ & $\mathrm{P}$ \\
\hline $\begin{array}{r}\text { May } \\
18 \\
25\end{array}$ & $\begin{array}{l}0.7 \pm 0.5 \\
0.7 \pm 1.0 \\
0.6 \pm 0.7\end{array}$ & $\begin{array}{l}1.4 \pm 1.5 \\
4.2 \pm 7.3 \\
0.7 \pm 0.4\end{array}$ & $\begin{array}{l}6.0 \pm 9.6 \\
0.8 \pm 0.7 \\
1.8 \pm 1.6\end{array}$ & $\begin{array}{l}0 \\
0 \\
2.3 \pm 4.5\end{array}$ & $\begin{array}{rr}1.0 \pm & 1.0 \\
10.4 \pm & 18.5 \\
0.6 \pm & 0.7\end{array}$ \\
\hline June $\begin{array}{r}1 \\
10 \\
15 \\
21 \\
29\end{array}$ & $\begin{array}{l}0.1 \pm 0.1 \\
0.4 \pm 0.5 \\
0 \\
0.5 \pm 0.2 \\
1.0 \pm 2.1\end{array}$ & $\begin{array}{l}0.2 \pm 0.3 \\
0.2 \pm 0.3 \\
0.7 \pm 0.5 \\
1.2 \pm 1.3 \\
1.0 \pm 2.1\end{array}$ & $\begin{array}{r}24.6 \pm 53.2 \\
4.8 \pm 8.3 \\
13.9 \pm 14.8 \\
12.3 \pm 6.6 \\
4.5 \pm 5.2\end{array}$ & $\begin{array}{l}0.3 \pm 0.4 \\
0.1 \pm 0.2 \\
0.1 \pm 0.2 \\
0.4 \pm 0.5 \\
0.2 \pm 0.3\end{array}$ & $\begin{array}{r}0.9 \pm 1.1 \\
103.4 \pm 92.0 \\
89.9 \pm 125.3 \\
52.2 \pm 63.4 \\
34.9 \pm 36.6\end{array}$ \\
\hline July 15 & $0.3 \pm 0.4$ & $0.9 \pm 0.9$ & 0 & 0 & $13.2 \pm 11.6$ \\
\hline $\begin{array}{l}\text { TOTAL } \\
\text { TOTAL Av. }\end{array}$ & $\begin{array}{l}4.3 \\
0.5 \pm 0.9\end{array}$ & $\begin{array}{l}10.5 \\
1.2 \pm 2.7\end{array}$ & $\begin{array}{l}68.7 \\
8.2 \pm 19.5\end{array}$ & $\begin{array}{l}3.4 \\
0.4 \pm 1.6\end{array}$ & $\begin{array}{l}306.5 \\
35.5 \pm 66.5\end{array}$ \\
\hline
\end{tabular}

*A, Ameroseius sp.; B, Belbodamaeus sp.; G, Galumna sp.; O, Ololaelaps sp.; P, Parasitus sp. 


\section{Gull Nesting Data}

Figure 1 shows gull nesting data for 1972, including nest initiation, egg laying, and egg hatching, expressed as percentage of the total. Egg laying peaked in the period 26-30 May, while nest initiation period was at a maximum in the same period. Egg hatching rose to a peak in the period 18-22 June.

In 1973 (Fig. 2) egg laying peaked between 12 May and 16 May, and nest initiation maximum again coincided. Egg hatching rose to a maximum between 11 June and 15 June.

\section{Discussion}

From Figs. 1 and 2 it is evident that the gull nest initiation and egg laying peaks are coincidentally at a maximum in both 1972 and 1973, although they occur 2 weeks later in 1972 . This is probably the result of a late spring in that year.

Figure 1 shows that in 1972 the total mite population increases slightly just before the egg laying, and nest initiation peaks, between 26 May and 31 May. Birds are on the nests at this time, providing warmth, humidity, and may serve as a source of food for the increasing mite population. One week later there is a drop in mite density, possibly due to predator-prey relationships among the mites. Another peak in mite density occurs 2 weeks later, just at the onset of the hatching period. By this time, the gulls have built up their nests sufficiently to provide suitable conditions for mite growth. Ten days later, there is another decline in the mite population, which again may be the result of a rising predator population. Two weeks after the egg hatching peak, the mite population density is at its greatest maximum, likely as a result of the maintenance of a suitable environment provided by the developing nestling gulls.

The 1973 data are similar to those for 1972 . Nest initiation and egg laying are at a maximum about 15 May, with a small secondary peak 10 days later (Fig. 2). The mite population shows corresponding fluctuations, the first rise occurring about 15 May, and a second 2 weeks later. This second density rise persists as a plateau which then increases to a maximum around 21 June, just after the egg hatching peak. The 1973 mite phenologies show a better correlation with gull breeding behaviour than those of the preceding year. This may be the result of a larger nest sample in 1973. However, it is evident that in both years the mites benefited from conditions brought about by the nesting gulls.

The overall mean number of mites per nest in 1973 was ca. 479 as compared with ca. 228 in 1972. This trend is reflected in the mean mite densities for the 2 years as well. The identified mites comprise 18 genera, representing 15 families. The most abundant genus is Parasitus, whose total count of 6,870 in 1973 makes up $28.9 \%$ of the total mites recovered. However, the bulk of the data is made up of mites from the supercohort Oribatei. For instance of 1,288 individuals the genus Galumna comprised $15.5 \%$ of the 1973 data. Members of the family Laelaptidae were present in smaller numbers. Other families were found infrequently.

Contrary to expectation, no feather mites (Analgesidae, Dermoglyphidae, and Proctophyllodidae) or skin mites (Epidermoptidae) have been recovered. Presumably, if any of these ectoparasites infest the birds, they remain on the integument of the host and, therefore, are not found in the nests. As well, no lice have been located, probably for the same reason. 

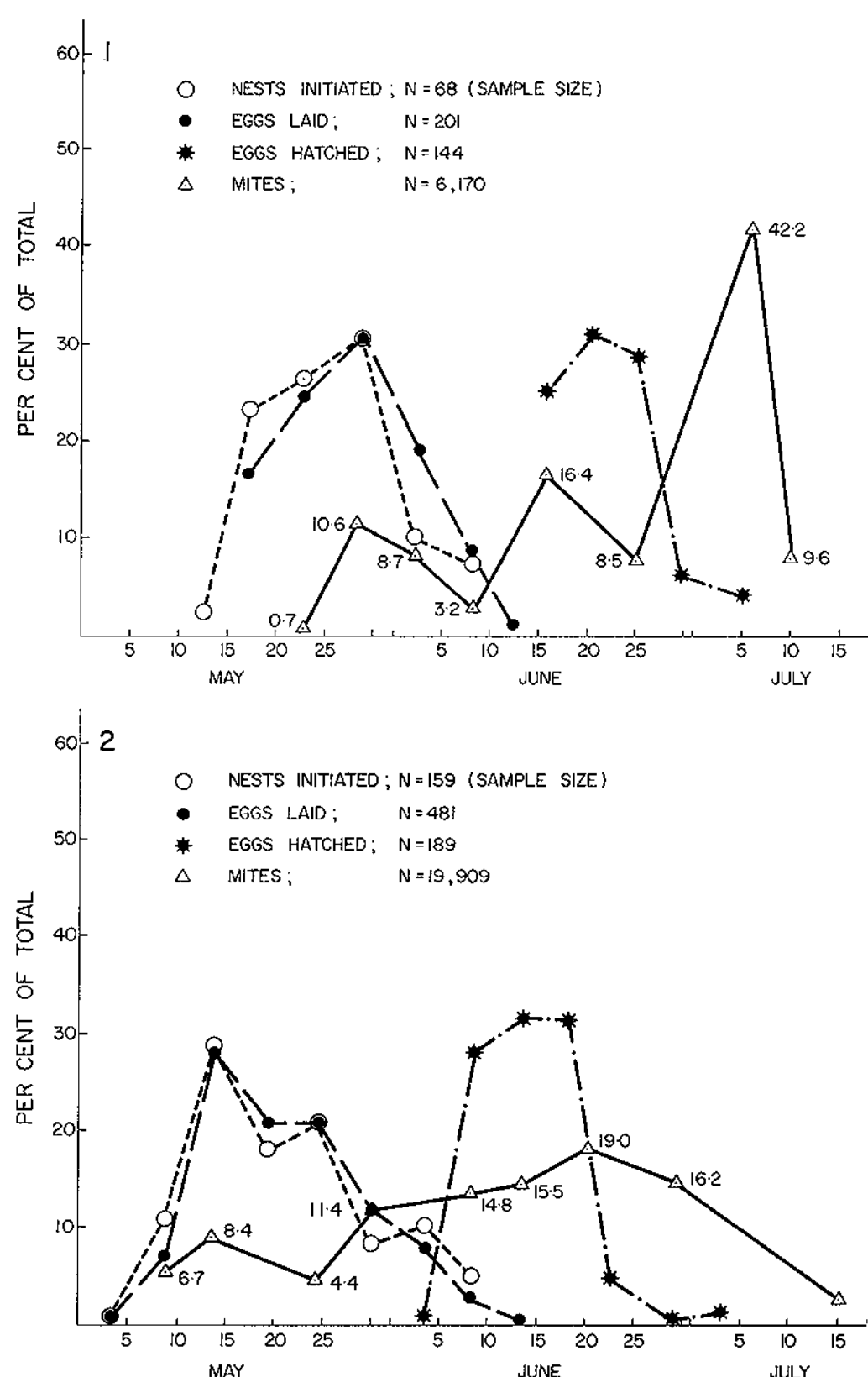

Figs. 1-2. Comparison of total mite population with nesting cycle of ring-billed gulls, 1972 and 1973 , respectively.

The five mite groups selected for phenological comparisons with the gull breeding curves were predators, Parasitus spp. and Ameroseius spp., and saprovores, Belbodamaeus spp., Galumna spp., and Ololaelaps spp. Figure 3 shows that the saprovores are most abundant after the egg laying or next initiation maximum: Belbodamaeus spp. about 15 May, Ololaelaps spp. around 25 May, Galumna spp. 


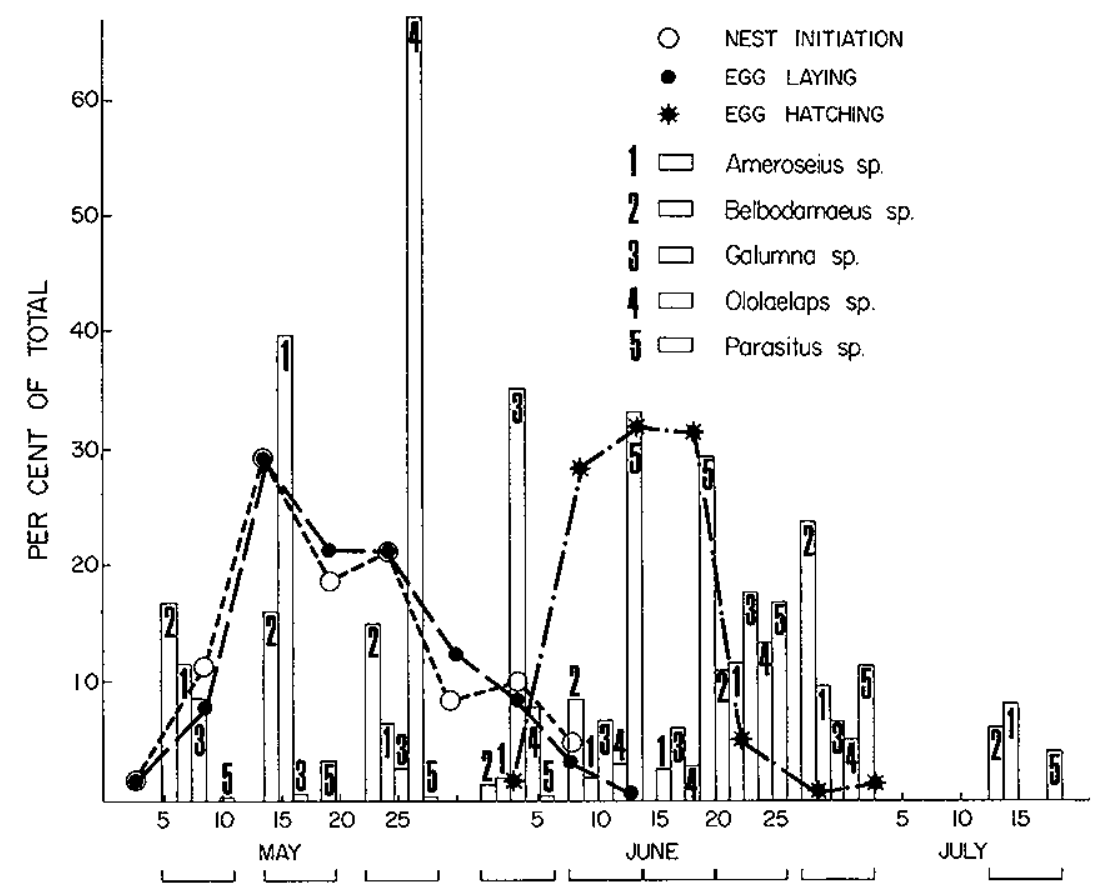

FIG. 3. Population changes of five mite genera during the nesting season of ring-billed gulls, 1973.

about 2 June. The saprovores are flourishing then because of abundant decaying matter. and favourable conditions of temperature and moisture provided by the nesting gulls. However, peak densities among the saprovores do not coincide, indicating that perhaps their population cycles are synchronized so as to minimize interspecific competition.

The predators reach their density peaks somewhat later in the season: Parasitus spp. is at a maximum coincidentally with the egg hatching peak, whereas Ameroseius spp. reaches its maximum 2 weeks later. These data are reasonable, since prey must be at a high level before the predators can begin to increase in number.

Although Ameroseius spp. and Belbodamaeus spp. are present in number before the egg laying peak and after nest vacation, following 15 July, their peak densities occur during the nesting period, indicating at least some relationship with gull breeding activity.

These results differ from those of Woodroffe and Southgate (1951), who observed that ectoparasites and scavengers precede the saprovoric mites in some passerine bird nests. Thus an analysis of the phenologies of all nest invertebrates is required before any general conclusions can be drawn.

Our data show considerable variability, as indicated by the large standard deviations in Tables I and II. Some of this variability is the result of few nest samples, differences in nest size, nest location, and moisture content.

Mean mite densities are significantly higher in wet nests, indicating that mites require humid conditions. The concentration of neighbouring gull nests apparently 
has no significant effect on mite densities in the nests. Presumably, mites are able to travel through the intervening leaf litter between nests. These results are in agreement with Ryder and Freitag (1973).

\section{Summary}

Mites from 69 ring-billed gull nests were counted and identificd during the summers of 1972 and 1973 . The total individuals recovered during the 2 years were, respectively, 6,170 and 19,909. A list (incomplete at the time of writing of this paper) of the identified mites includes 18 genera in 15 families.

Nests from high and low gull density areas showed no significant differences in mite densities. However, nests from moist habitats had significantly greater mite densities than those from dry areas.

For both years, the mites as a whole show three density maxima during the season, one almost coinciding with the egg laying (or nest initiation) peak, a second somewhat later (a plateau in 1973), and a large maximum after the egg hatching peak. These maxima probably occur as a result of the favourable conditions arising from the gull breeding activities.

The saprovores, Belbodamaeus spp., Galumna spp., and Ololaelaps spp., show peak densities after the egg laying or nest initiation maximum. However, their individual peaks do not coincide. This may reduce interspecific competition. On the other hand, the predators, Parasitus spp. and Ameroseius spp., reach a maximum density during or after the time of peak egg hatching, which may be the result of preceding abundance of prey.

Lower mite densities in leaf litter as compared with nests, support the hypothesis that the gull nests serve as focal points for mite growth. More conclusive statements about the relationship between the ring-billed gulls and their associated nest invertebrates can be made only after a complete analysis of the remaining mite species and of the other collected arthropods.

\section{Acknowledgments}

We wish to express our thanks to Mr. D. McLachlan for collecting the gull nests and field data, Dr. E. E. Lindquist for identifying the mites, and Miss J. Pekkala, Mr. S. Spivak, and Ms. S. Pelky for technical assistance. The study was supported through National Research Council of Canada grants held by R. Freitag and J. P. Ryder.

\section{References}

Boyd, E. M. 1949. A new genus and species of mite from the nasal cavity of the Ring-billed Gull (Acarina: Epidermoptidae). J. Parasit. 35: 295-300.

Coombs, C. J. F. 1960. Ectoparasites and nest fauna of rooks and jackdaws in Cornwall. Ibis 102: 326-328.

Hicks, E. A. 1959. Check-list and bibliography on the occurrence of insects in birds' nests. Iowa State Press, Ames, Yowa. $681 \mathrm{pp}$.

Mason, E. A. 1944. Parasitism by Protocalliphora and management of cavity-nesting birds. J. Wildl. Mgmt 8: 232-247.

Moss, W. W. 1972. Some ecological relationships of purple martins and their acarine ectoparasites. J. med. ent. $9(6): 599$.

Nolan, V. 1955. Invertebrate nest associates of the prairie warbler. Auk 72. 55-61.

Owen, D. F. 1954. Protocalliphora in birds' nests. Brit. Birds 47: 236-243.

Phillis, W. 1972. Seasonal abundance of Dermanyssus hirundinis and D. americanus (Mesostigmata: Dermanyssidae) in nests of the house sparrow. J. med. ent. 9(1): 111-112. 
Rao, T. R. and P. K. Rajagopalan. 1970. Arthropod fauna of the nests of some common birds in Poona, India, with special reference to blood sucking forms. J. Bombay nat. Hist. Soc. 64: $414-429$.

Ryder, J. P. and R. Freitag. 1973 (unpub.). The effect of nest size on invertebrate population densities.

Threlfall, W. 1968. Studies on the helminth parasites of the American herring gull (Larus argentatus Pont) in Newfoundland. Can. J. Zool 46: 1119-1126.

Vermeer, K. 1969 . Comparison of the helminth fauna of California gulls, Larus californicus and ring-billed gulls, Larus delawarensis, at Beaverhill and Miquelon Lakes, Alberta. Can. J. Zool. 47: 267-270.

Woodroffe, G. E. 1953. An ecological study of the insects and mites in the nests of certain birds in Britain. Bull. ent. Res. 44: 739-772.

Woodroffe, G. E. and B. J. Southgate. 1951. Birds' nests as a source of domestic pests. Proc. zool. Soc. Lond. 121: 55-62.

(Received 23 November 1973) 